\title{
Mass spectrometry characterisation of fatty acids from metabolically engineered soybean seeds
}

\author{
André M. Murad • Giovanni R. Vianna • Alex M. Machado • \\ Nicolau B. da Cunha • Cíntia M. Coelho • Valquiria A. M. Lacerda • \\ Marly C. Coelho $•$ Elibio L. Rech
}

Received: 16 October 2013 /Revised: 7 February 2014 / Accepted: 19 February 2014 / Published online: 21 March 2014

(C) Springer-Verlag Berlin Heidelberg 2014

\begin{abstract}
Improving the quality and performance of soybean oil as biodiesel depends on the chemical composition of its fatty acids and requires an increase in monounsaturated acids and a reduction in polyunsaturated acids. Despite its current use as a source of biofuel, soybean oil contains an average of $25 \%$ oleic acid and $13 \%$ palmitic acid, which negatively impacts its oxidative stability and freezing point, causing a high rate of nitrogen oxide emission. Gas chromatography and ion mobility mass spectrometry were conducted on soybean fatty acids from metabolically engineered seed extracts to determine the nature of the structural oleic and palmitic acids. The soybean genes FAD2-1 and FatB were placed under the control of the 35SCaMV constitutive promoter, introduced to soybean embryonic axes by particle bombardment and downregulated using RNA interference technology. Results indicate that the metabolically engineered plants exhibited a significant increase in oleic acid (up to $94.58 \%$ ) and a reduction in palmitic acid (to $<3 \%$ ) in their seed oil content. No structural differences were observed between the fatty acids of the transgenic and non-transgenic oil extracts.
\end{abstract}

Keywords Soybean oil $\cdot$ Biodiesel $\cdot$ Metabolic engineering

André M. Murad and Giovanni R. Vianna contributed equally to this work.

Electronic supplementary material The online version of this article (doi:10.1007/s00216-014-7709-8) contains supplementary material, which is available to authorized users.

A. M. Murad · G. R. Vianna • A. M. Machado • N. B. da Cunha • C. M. Coelho $\cdot$ V. A. M. Lacerda $\cdot$ M. C. Coelho $\cdot$ E. L. Rech $(\bowtie)$ Embrapa Genetic Resources and Biotechnology,

Laboratory of Synthetic Biology, Parque Estação Biológica, PqEB, Av. W5 Norte, 70770-917 Brasília, DF, Brazil

e-mail: elibio.rech@embrapa.br

\section{Introduction}

Energy needs and environmental concerns have induced worldwide interest in developing fuels based on renewable non-fossil fuel sources. Biodiesels from plants [1], algae [2], bacteria [3] and yeast [4] are rapidly emerging as potential renewable fuel sources. Most plant oils are primarily composed of five fatty acids: palmitate (16:0), stearate (18:0), oleate (18:1), linoleate $(18: 2)$ and linolenate $(18: 3)$ [1, 5, 6]. Palmitate and stearate are saturated fatty acids, oleate is a monounsaturated fatty acid, and linoleate and linolenate are polyunsaturated fatty acids. However, most plant oils used commercially as biodiesel feedstocks have high levels of polyunsaturated fatty acids, which decreases the stability of the oil, affects the cetane number [7] and directly limits their use as biofuels. Biodiesel with a high monounsaturated fatty acid (oleate) content has desirable characteristics for fuel performance such as ignition quality, nitrogen oxide $\left(\mathrm{NO}_{x}\right)$ emissions and oxidative stability [8]. Therefore, from a compositional standpoint, plant oils high in oleic acid and low in palmitic acid are good candidates for developing a high-performance biodiesel [9].

Soybean oil is essentially composed of triacylglycerol, a product of fatty acid esterification, and its performance as a fuel depends directly on its fatty acid composition. The metabolic manipulation of fatty acids in soybeans as it relates to improving oil quality and performance has been studied [1, 10]. Plants have been developed with genetically modified oils via mutation [11] and recombinant DNA technology [10], followed by selective breeding programs. Both approaches require screening to ensure optimal expression, stability across diverse growing environments and acceptable agronomic performance of the derived lines. Mutant soybean lines have been developed and introduced into a breeding program aiming at manipulating their fatty acid composition [11]. However, the results thus far have indicated that in addition to the length of time required to develop advanced varieties via sexual 
crossings, the main challenge in developing commercial lines is achieving the required agronomic characteristics, such as high seed yield. Early studies have indicated that these constraints could be due to pleiotropy or unfavourable linkages during sexual crossings [12]. Over the last decade, the fatty acid composition of oil seeds such as soybean and Jatropha curcas has been successfully altered via metabolic engineering [13-15, 10, 16]. Down-regulating FAD2-1 and FatB using interference RNA has enabled the production of soybeans with significantly higher oleic acid content (up to $85 \%$ ) and reduced levels of palmitic acid $(<5 \%)$, which improve its agronomic and biodiesel fuel performances [10]. These results demonstrate that engineering the fatty acid metabolism of soybean seeds allows the production of biodiesel with improved fuel performance, stability and $\mathrm{NO}_{x}$ emissions [10].

Monitoring the composition and structural quality of the fatty acids in the metabolically engineered seed lines of $T_{0}$ transgenic plants $/ T_{1}$ seeds using heterozygous individual segregating seed, while maintaining germination without waiting for further progeny generation, is essential. These possibilities provide the basis by which one can decide whether to propagate advanced progenies for generating homozygous lines. A routine approach to evaluating fatty acid composition was developed using optimised capillary GC-MS [17]. This new ability to determine the structures of the fatty acids was the result of significant technological advances in mass spectrometry $[18,19]$. Despite the availability of a range of mass spectrometry procedures [20-22], the structural analysis of fatty acids has been performed on few metabolically engineered oil seed plants $[14,10]$.

In our study, we have generated metabolically engineered transgenic soybean lines with high levels of oleic acid and decreased levels of palmitic acid by down-regulating the expression of $\Delta 12$ desaturase (FAD2-1) and palmitoyl thioesterase (FatB1a) under the control of a constitutive promoter and RNA interference technology. We have also determined the composition and structural characterisation of the fatty acids in these lines via mass spectrometry.

\section{Materials and methods}

Synthetic fatty acid sequences and the selective marker

To generate the fatty acid down-regulated RNAi soybean construct, we used two gene-specific 300-bp fragments corresponding to the cDNA coding regions of SoyFAD2-1 (GenBank accession L43920.1, nt 272 to 571) and SoyFatB1a (GenBank accession DQ861997.1, nt 65 to 364). These cDNA fragments were assembled in tandem to form a 600-bp fragment. An in silico restriction analyses of the 600-bp sequence indicated an $\mathrm{Xba \textrm {I }}$ site (TCTAGA) at position 533. The first base, $\mathrm{T}$ (underlined), was deleted to remove the restriction site.
A synthetic 599-bp fragment corresponding to the FAD and FAT

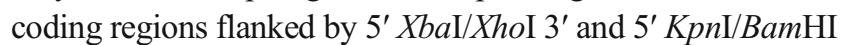
$3^{\prime}$ restriction sites was produced (DNA2.0 Inc., Menlo Park, CA 94025, USA). The synthetic fragment was inserted in the sense direction into the $X h o \mathrm{I} / \mathrm{KpnI}$ sites and in the antisense direction into the $B a m \mathrm{HI} / \mathrm{XbaI}$ sites of pKannibal [23] to generate the pSoybiofuell RNAi vector. In the pSoybiofuel1 vector, the total hairpin sequences were under the control of the constitutive $35 \mathrm{SCaMV}$ promoter and OCS terminator. The pAC321 vector carrying the mutated ahas gene from Arabidopsis thaliana, which confers tolerance to the herbicide Imazapyr $^{\circledR}$, was used as a selective marker [24].

\section{Soybean gene transfer}

The plasmids pSoybiofuel1 and pAC321 [25, 24] were cobombarded in a 1:1 ratio into the apical meristematic region of somatic embryonic axes from mature soybean seeds (cultivar conquista, Embrapa, Brazil) via particle bombardment as previously described [24]. The putative plants grown in Imazapyr ${ }^{\circledR}$-selective medium were analysed by PCR for both transgenes. The PCR-positive $\mathrm{T}_{0}$ plants were acclimatised and cultivated in soil under greenhouse conditions until they produced seeds. All seeds were harvested and used individually for molecular and biochemical analyses.

\section{PCR analyses}

A small segment (approximately $1 \mathrm{~mm}^{2}$ ) of the cotyledon from each $T_{1}$ and $T_{2}$ seed was excised for DNA isolation. The segment from the seed was removed from the opposite side to the embryonic axis to allow later seed sowing and plant development. The plant DNA was isolated according to the technique of Doyle and Doyle [26]. The PCRs contained $10 \mathrm{mM}$ Tris- $\mathrm{HCl}$ ( $\mathrm{pH} 8.4$ ), $50 \mathrm{mM} \mathrm{KCl}, 2 \mathrm{mM} \mathrm{MgCl}{ }_{2}$, $160 \mathrm{mM}$ each of dNTP, $2 \mathrm{U}$ Taq polymerase (Invitrogen), $20 \mathrm{ng}$ of DNA and $200 \mathrm{nM}$ of one of the following pairs of primers: KANNIf (CCACTATCCTTCGCAAGACC) and PDKr (TAACTATTTTATACTAAAAGGA); PDKf (TTTC TAAATAATACTTGTAGTT) and KANNIr (CGATCATA GGCGTCTCGCAT) or ahasp124 (ACTAGAGATTCCAG CGTCAC) and ahas500c (GTGGCTATACAGATACCTGG). The DNA was pre-denatured at $95^{\circ} \mathrm{C}$ for $5 \mathrm{~min}$ and amplified for 35 cycles of $95^{\circ} \mathrm{C}$ for $1 \mathrm{~min}, 55^{\circ} \mathrm{C}$ for $1 \mathrm{~min}$ and $73^{\circ} \mathrm{C}$ for $1 \mathrm{~min}$, with a final cycle at $72{ }^{\circ} \mathrm{C}$ for $7 \mathrm{~min}$. The expected amplification products using the given primers contained 728 and $835 \mathrm{bp}$ for the forward and reverse bands, respectively, and $685 \mathrm{bp}$ for the ahas gene.

Preparing the oil samples for mass spectrometry

Oil from the soybean seeds was extracted and esterified as previously described [27], with modifications. Soybean pods 
Table 1 GC-MS results yielding the oil composition of the transgenic soybean seed line 65 and its sub-lines. Sample number 22 is a non-transgenic event and was used as a negative reference. The standard deviation varies from 0.1 to $0.6 \%$ from injection-to-injection

\begin{tabular}{|c|c|c|c|c|c|c|c|}
\hline Sample & Generation & Line/seed & $\%$ Methyl palmitate & $\%$ Methyl stearate & $\%$ Methyl oleate & $\%$ Methyl linoleate & $\%$ Methyl linolenate \\
\hline 1 & $\mathrm{~T} 1$ & $65-25$ & 2.12 & 1.58 & 94.58 & 0.71 & 1.01 \\
\hline 2 & $\mathrm{~T} 1$ & $65-14$ & 3.50 & 1.47 & 85.42 & 7.57 & 2.04 \\
\hline 3 & $\mathrm{~T} 1$ & $65-01$ & 5.55 & 2.11 & 79.29 & 8.46 & 4.59 \\
\hline 4 & $\mathrm{~T} 1$ & $65-11$ & 4.33 & 1.85 & 85.43 & 4.98 & 3.41 \\
\hline 5 & $\mathrm{~T} 1$ & $65-16$ & 3.92 & 1.56 & 86.35 & 5.52 & 2.65 \\
\hline 6 & $\mathrm{~T} 1$ & $65-17$ & 4.88 & 1.98 & 80.47 & 7.85 & 4.82 \\
\hline 7 & $\mathrm{~T} 1$ & $65-19$ & 2.80 & 1.48 & 93.27 & 1.28 & 1.17 \\
\hline 8 & $\mathrm{~T} 1$ & $65-24$ & 1.64 & 1.62 & 67.33 & 23.66 & 5.75 \\
\hline 9 & $\mathrm{~T} 1$ & $65-26$ & 3.61 & 1.56 & 91.79 & 1.69 & 1.35 \\
\hline 10 & $\mathrm{~T} 1$ & $65-105$ & 0.40 & 0.11 & 85.09 & 11.57 & 2.83 \\
\hline 11 & $\mathrm{~T} 1$ & $65-113$ & 3.06 & 1.30 & 84.52 & 6.63 & 4.49 \\
\hline 12 & $\mathrm{~T} 1$ & $65-114$ & 1.42 & 1.70 & 91.74 & 2.11 & 3.03 \\
\hline 13 & $\mathrm{~T} 1$ & $65-115$ & 5.05 & 1.25 & 86.05 & 4.36 & 3.29 \\
\hline 14 & $\mathrm{~T} 1$ & $65-120$ & 2.11 & 1.65 & 80.75 & 10.73 & 4.76 \\
\hline 15 & $\mathrm{~T} 1$ & $65-121$ & 2.23 & 1.38 & 84.63 & 7.14 & 4.62 \\
\hline 16 & $\mathrm{~T} 1$ & $65-123$ & 4.33 & 1.52 & 82.68 & 6.75 & 4.72 \\
\hline 17 & $\mathrm{~T} 1$ & $65-127$ & 2.94 & 1.19 & 87.50 & 4.58 & 3.79 \\
\hline 18 & $\mathrm{~T} 1$ & $65-135$ & 1.87 & 1.39 & 81.78 & 10.89 & 4.07 \\
\hline 19 & $\mathrm{~T} 1$ & $65-140$ & 2.78 & 1.11 & 92.75 & 1.21 & 2.15 \\
\hline 20 & $\mathrm{~T} 1$ & $65-141$ & 2.16 & 1.28 & 89.73 & 3.66 & 3.17 \\
\hline 21 & $\mathrm{~T} 1$ & $65-144$ & 3.29 & 1.33 & 82.56 & 7.74 & 5.08 \\
\hline 22 & $\mathrm{~T} 1$ & $122-22$ & 3.37 & 3.41 & 24.12 & 63.22 & 5.88 \\
\hline 23 & $\mathrm{~T} 2$ & $65-25-13$ & 2.54 & 0.58 & 94.74 & 0.72 & 1.34 \\
\hline 24 & $\mathrm{~T} 2$ & $65-25-14$ & 1.89 & 0.20 & 97.81 & 0.17 & 0.13 \\
\hline 25 & $\mathrm{~T} 2$ & $65-25-15$ & 3.72 & 0.30 & 92.44 & 2.07 & 1.47 \\
\hline 26 & $\mathrm{~T} 2$ & $65-25-18$ & 3.30 & 0.30 & 94.37 & 1.06 & 0.97 \\
\hline 27 & $\mathrm{~T} 2$ & $65-25-19$ & 2.28 & 0.38 & 95.51 & 0.80 & 1.03 \\
\hline 28 & $\mathrm{~T} 2$ & $65-25-20$ & 8.02 & 0.48 & 81.99 & 8.13 & 1.38 \\
\hline 29 & $\mathrm{~T} 2$ & $65-25-33$ & 5.58 & 0.38 & 77.41 & 15.43 & 1.20 \\
\hline 30 & $\mathrm{~T} 2$ & $65-25-37$ & 7.43 & 0.38 & 82.17 & 9.51 & 0.51 \\
\hline 31 & $\mathrm{~T} 2$ & $65-25-38$ & 3.50 & 0.69 & 90.18 & 4.00 & 1.63 \\
\hline 32 & $\mathrm{~T} 2$ & $65-25-40$ & 2.00 & 0.30 & 97.04 & 0.66 & NA \\
\hline 33 & $\mathrm{~T} 2$ & $65-25-55$ & 4.25 & 0.91 & 91.35 & 2.10 & 1.39 \\
\hline 34 & $\mathrm{~T} 2$ & $65-25-56$ & 2.16 & 0.66 & 96.83 & 0.22 & 0.13 \\
\hline 35 & $\mathrm{~T} 2$ & $65-25-60$ & 4.30 & 0.77 & 88.48 & 4.63 & 1.82 \\
\hline 36 & $\mathrm{~T} 2$ & $65-25-66$ & 2.90 & 0.23 & 96.15 & 0.22 & 0.50 \\
\hline 37 & $\mathrm{~T} 2$ & $65-25-68$ & 2.47 & 0.31 & 97.22 & NA & NA \\
\hline 38 & $\mathrm{~T} 2$ & $65-25-69$ & 3.93 & 0.81 & 89.82 & 3.97 & 1.47 \\
\hline 39 & $\mathrm{~T} 2$ & $65-25-70$ & 5.60 & 0.77 & 83.71 & 8.11 & 1.81 \\
\hline 40 & $\mathrm{~T} 2$ & $65-25-81$ & 3.36 & 0.72 & 89.62 & 4.87 & 1.43 \\
\hline 41 & $\mathrm{~T} 2$ & $65-25-82$ & 2.87 & 0.92 & 93.82 & 1.06 & 1.33 \\
\hline 42 & $\mathrm{~T} 2$ & $65-25-83$ & 5.31 & 0.73 & 77.12 & 13.95 & 1.89 \\
\hline 43 & $\mathrm{~T} 2$ & $65-25-86$ & 1.72 & 0.38 & 96.94 & 0.30 & 0.66 \\
\hline 44 & $\mathrm{~T} 2$ & $65-25-94$ & 4.48 & 0.75 & 88.04 & 4.29 & 2.44 \\
\hline
\end{tabular}

from $\mathrm{T}_{0}$ transgenic and non-transgenic plants were harvested. The $\mathrm{T}_{1}$ and $\mathrm{T}_{2}$ seeds were collected and stored individually below $4{ }^{\circ} \mathrm{C}$. Using a scalpel blade, a 1-2-mm-thick section weighing approximately $10 \mathrm{mg}$ was excised from the seed cotyledon, as previously described. The section was ground using a mortar and pestle. The sample powder was transferred 


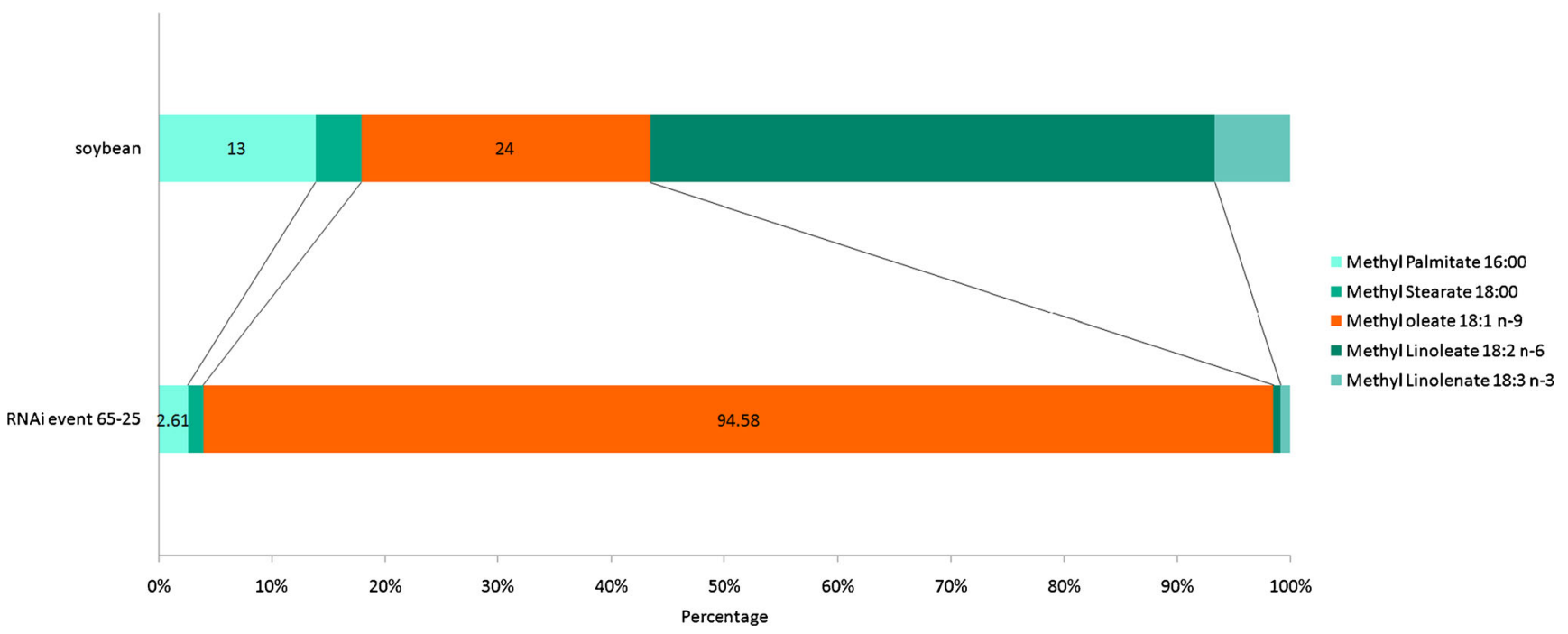

Fig. 1 Soybean fatty acid GC-MS profile. Percentage of soybean fatty acids in the oil extracts from transgenic seed line 65

to a glass flask and dried overnight in an oven at $90{ }^{\circ} \mathrm{C}$. To each flask, $500 \mu \mathrm{L}$ of a $0.5 \mathrm{~N} \mathrm{KOH}-$ methanol solution was added, and the mixture was vortexed for $15 \mathrm{~s}$. Then, the flasks were heated in an oven at $80{ }^{\circ} \mathrm{C}$ for $60 \mathrm{~min}$. To each flask, $2 \mathrm{~mL}$ of an acid-methanol solution $(6 \mathrm{~mL}$ $\mathrm{H}_{2} \mathrm{SO}_{4}$ in methanol) was added, and the samples were vortexed for $3 \mathrm{~min}$ and heated in an oven at $80{ }^{\circ} \mathrm{C}$ for an additional $60 \mathrm{~min}$. The samples were cooled at room temperature for $10 \mathrm{~min}$, and $2 \mathrm{~mL}$ of hexane was added, followed by vortexing for $3 \mathrm{~min}$. The samples were allowed to separate into phases for $45 \mathrm{~min}$. Then, $1 \mathrm{~mL}$ of the supernatant was collected and placed in a capped vial for a GC autosampler. Standards of palmitic acid (Sigma-76119), stearic acid (Sigma-85679), linolenic acid (Sigma-62160), linoleic acid (Sigma-62230) and oleic acid (Sigma-75040) were also esterified using the aforementioned method and used for GC-MS calibration. For the LC-MS analysis, $400 \mu \mathrm{L}$ of the GC-MS prepared sample corresponding to line 65-25 was placed in a new glass vial and dried in a $\mathrm{N}_{2}$ flux. Methanol ( $1 \mathrm{~mL}$, LC-MS grade) was added, and the sample was vortexed for $30 \mathrm{~s}$. This solution was directly infused into the MS.

\section{GC-MS analysis}

Gas chromatography mass spectrometry was performed using a Shimadzu GC-2010 and a Shimadzu GCMS-QP2010 equipped with an autosampler. Two microlitres was applied to an OmegaWax 250 capillary column $(30 \mathrm{~m} \times 0.25 \mathrm{~mm} \times$ $0.25 \mu \mathrm{m}$ ) from Supelco (Sigma-24136). The following chromatographic conditions were set: initial temperature, $50{ }^{\circ} \mathrm{C}$; final temperature, $240^{\circ} \mathrm{C}$; injection temperature, $250^{\circ} \mathrm{C}$; and rate, $5{ }^{\circ} \mathrm{C} / \mathrm{min}$ up to $240{ }^{\circ} \mathrm{C}$ then hold at $240{ }^{\circ} \mathrm{C}$ for $10 \mathrm{~min}$ (total run time $=58 \mathrm{~min}$ ). A linear flow of $2 \mathrm{~mL} / \mathrm{min}$ with a helium pressure of $117.6 \mathrm{kPa}$ was used in a total flow of
Fig. 2 Soybean fatty acid GCMS profiles for the oil extracts from transgenic line 65 and its sub-lines. Retention times from the different soybean lines. Each colour represents one line

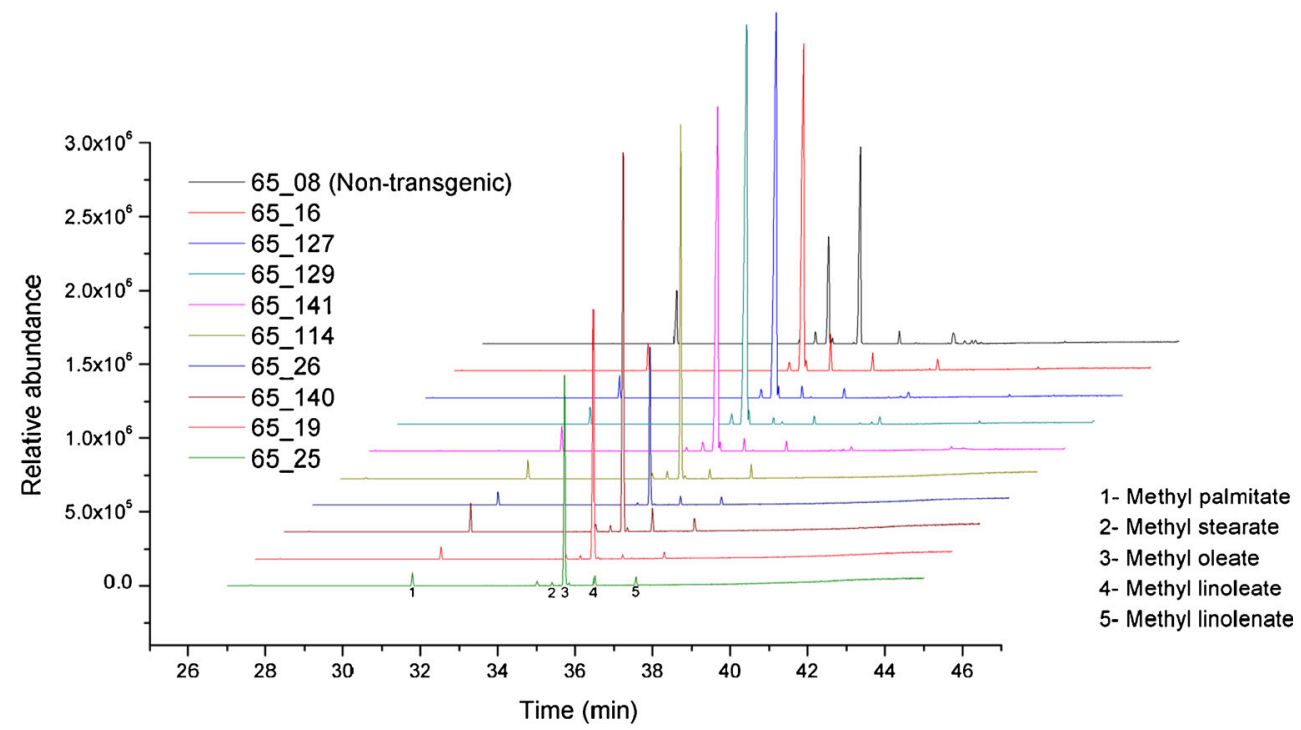


Fig. 3 MicrO-TOF Q exact mass spectra $(\mathrm{m} / \mathrm{z})$ from the oil extracted and esterified from line $65-25$

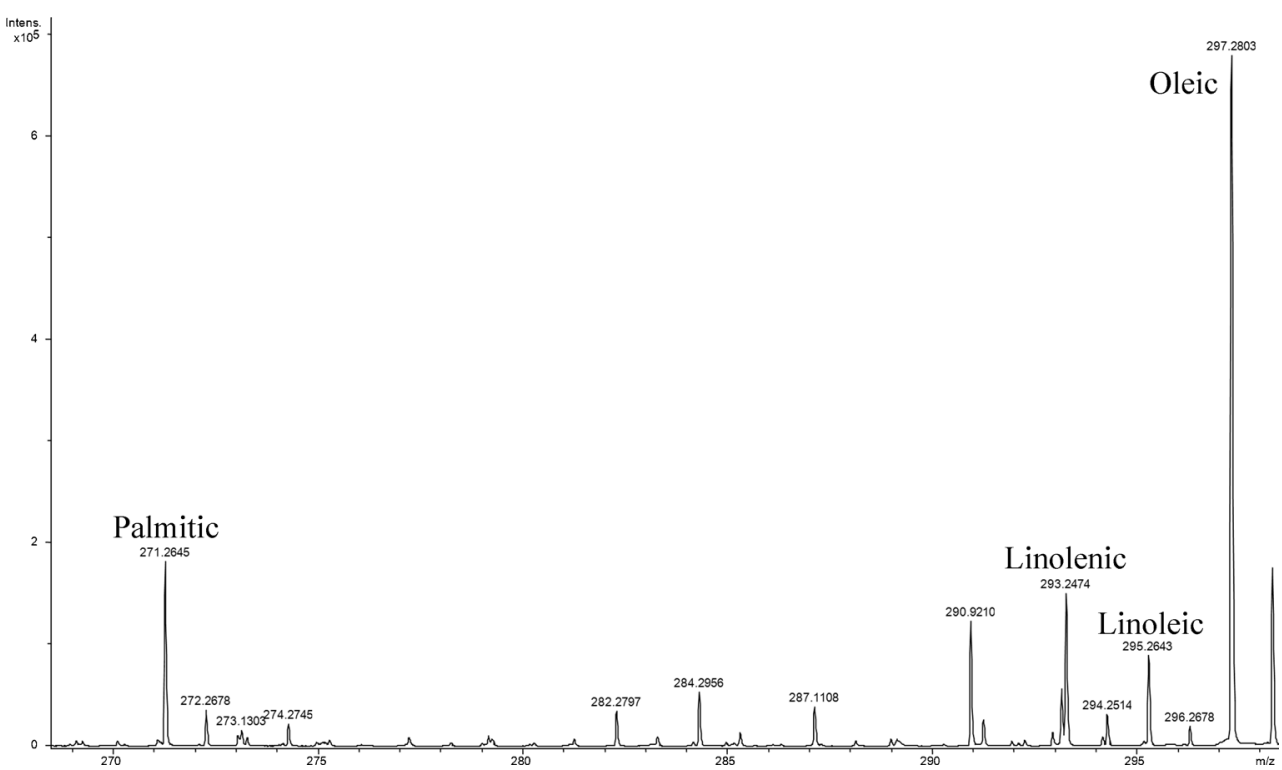

$25 \mathrm{~mL} / \mathrm{min}$. The linear velocity was set at $51.3 \mathrm{~cm} / \mathrm{s}$ with a purge at $3 \mathrm{~mL} / \mathrm{min}$ and a split ratio of 10 . The mass spectrometry was operated at a temperature of $250{ }^{\circ} \mathrm{C}$ with an $833-\mathrm{Hz}$ scan speed from $100-500 \mathrm{~m} / z$ over $58 \mathrm{~min}$. The chromatography peaks and MS fragmentation data were searched in the FAME fragment database.

Exact mass spectrometry and ion mobility mass spectrometry

The samples previously prepared for GC-MS were analysed in a MicrO-TOF Q II electrospray ionisation mass spectrometer (Bruker Daltonics) and a Synapt G2 high definition mass spectrometer (Waters, USA). For the Synapt G2 analysis, a nanospray source (at $600 \mathrm{~nL} / \mathrm{min}$ ) was used in the positive ion mode with the following conditions: analyser, resolution mode; capillary, $3.0 \mathrm{kV}$; sampling cone, 30.0; extraction cone, 6.0 ; source temperature, $70{ }^{\circ} \mathrm{C}$; desolvation temperature, $200{ }^{\circ} \mathrm{C}$; cone gas flow, $0.0 \mathrm{~L} / \mathrm{h}$; nanoflow gas pressure, 0.2 Bar; purge gas flow, $800.0 \mathrm{~mL} / \mathrm{h}$; desolvation gas flow, 800.0 L/h; LM resolution, 4.9; and HM resolution, 15.0. The mass spectrometry was externally calibrated using ion series from a sodium formate solution. The fragment analyses were performed in the MS/MS mode, and the data were collected from 10 to $300 \mathrm{~m} / \mathrm{z}$ over $5 \mathrm{~min}$. The collision energy was applied in a trap cell, ramping from 6 to $35 \mathrm{eV}$, and the LM resolution was set to 23.9. Ion mobility was also evaluated in the resolution mode, adjusting the quadrupole radio frequency to select each FAME with an LM resolution of 23.9. The IMS
Fig. 4 Molecular rearrangements of the fatty acid methyl acids produced in the collision cell. A Formation of the base peak of 87 $\mathrm{m} / \mathrm{z}$. B Loss of OCH3 $(31 \mathrm{~m} / \mathrm{z})$. C Loss of CH2COHOCH3 $(74 \mathrm{~m} / \mathrm{z})$

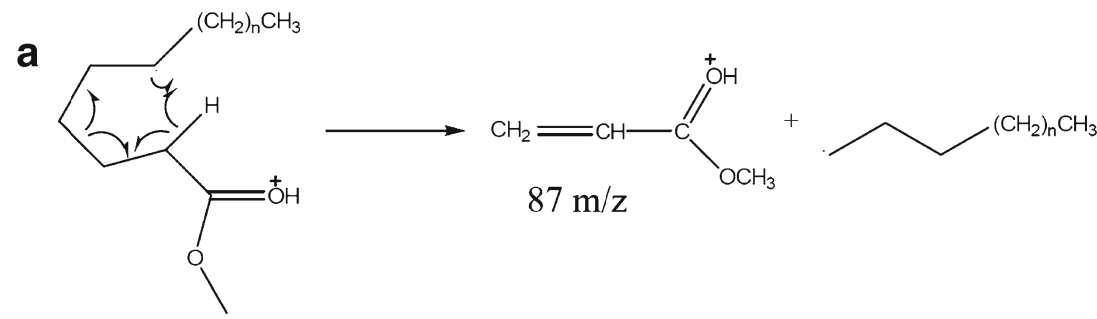

b
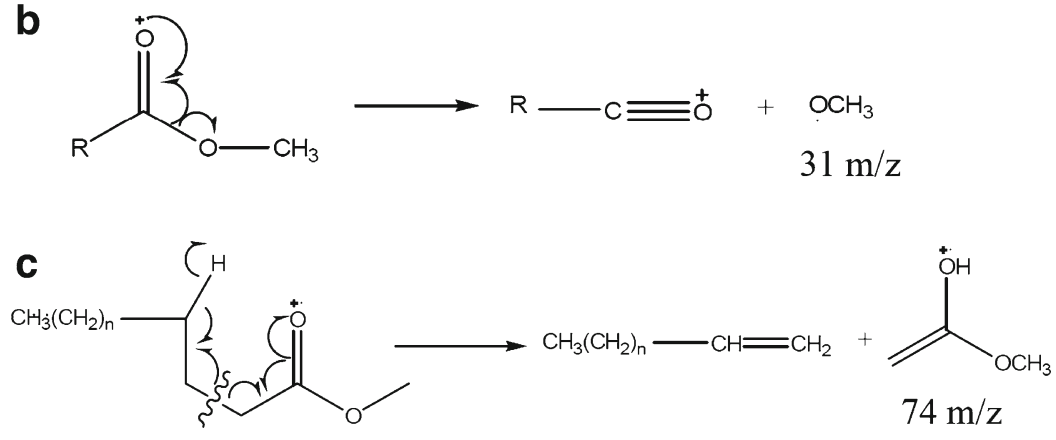


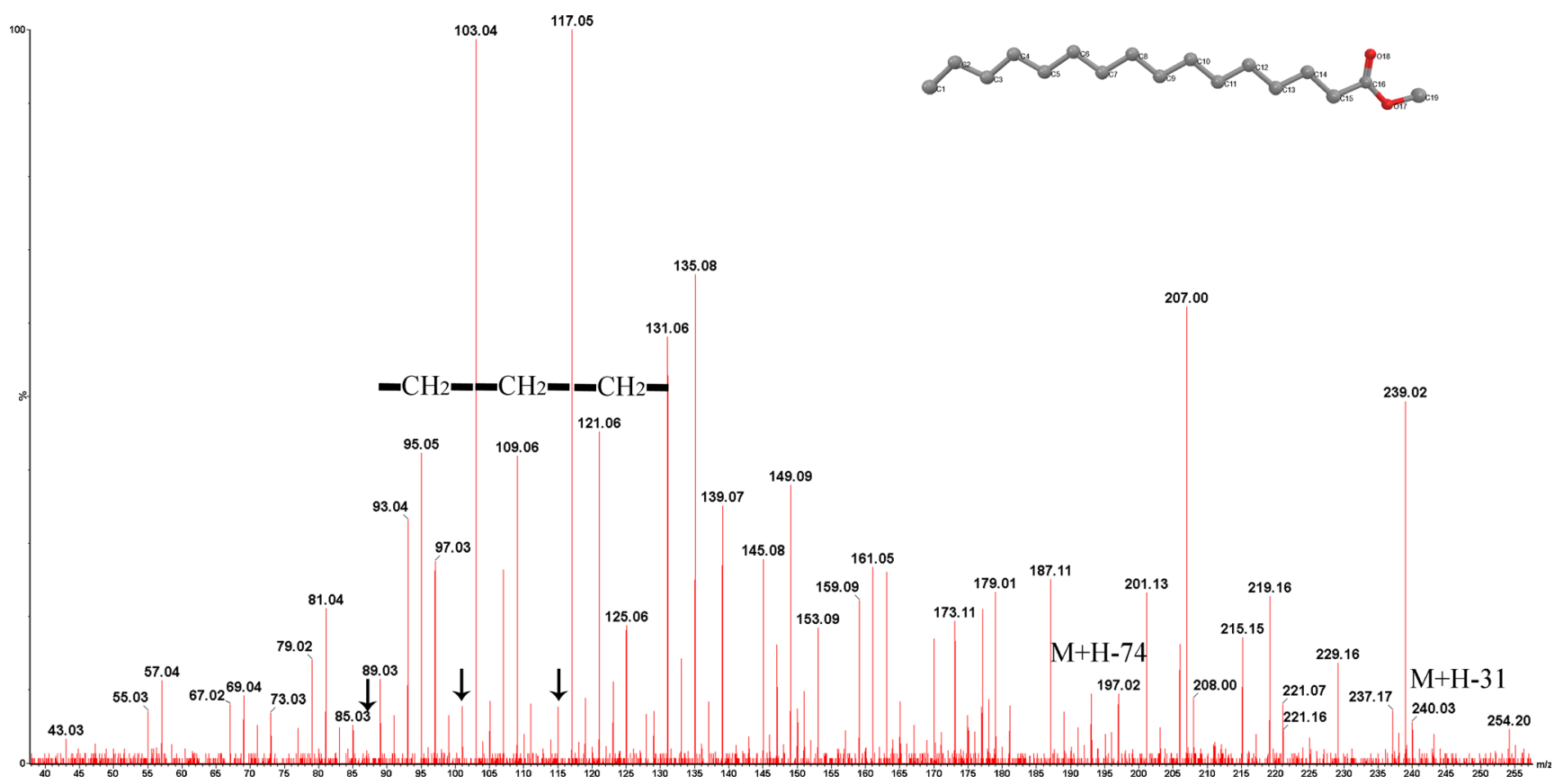

Fig. 5 Palmitic methyl ester fragmentation patterns. The molecular structure of this FAME and the $\mathrm{CH}_{2}$ loss are shown in detail. The arrows indicate the ion series of $87 \mathrm{~m} / \mathrm{z}$

gas flow was set to $90 \mathrm{~mL} / \mathrm{min}$, and the helium gas flow to $180 \mathrm{~mL} / \mathrm{min}$. The IMS wave velocity and wave height were set such that the TICs were observed in the centre of the drift tube, and these values were maintained for all samples. The palmitic methyl ester spectra were obtained from 270 to $275 \mathrm{~m} / \mathrm{z}$. The linolenic methyl ester spectra were obtained from 290 to 297 $\mathrm{m} / \mathrm{z}$. The linoleic methyl ester spectra were obtained from 294 to $300 \mathrm{~m} / z$. The oleic methyl ester spectra were obtained from 295 to $300 \mathrm{~m} / \mathrm{z}$. The exact mass and MS/MS experiments were also performed in a MicrO-TOF Q II electrospray ionisation mass spectrometer using a standard electrospray probe and internal calibration for sub-ppm mass errors in the MS mode.

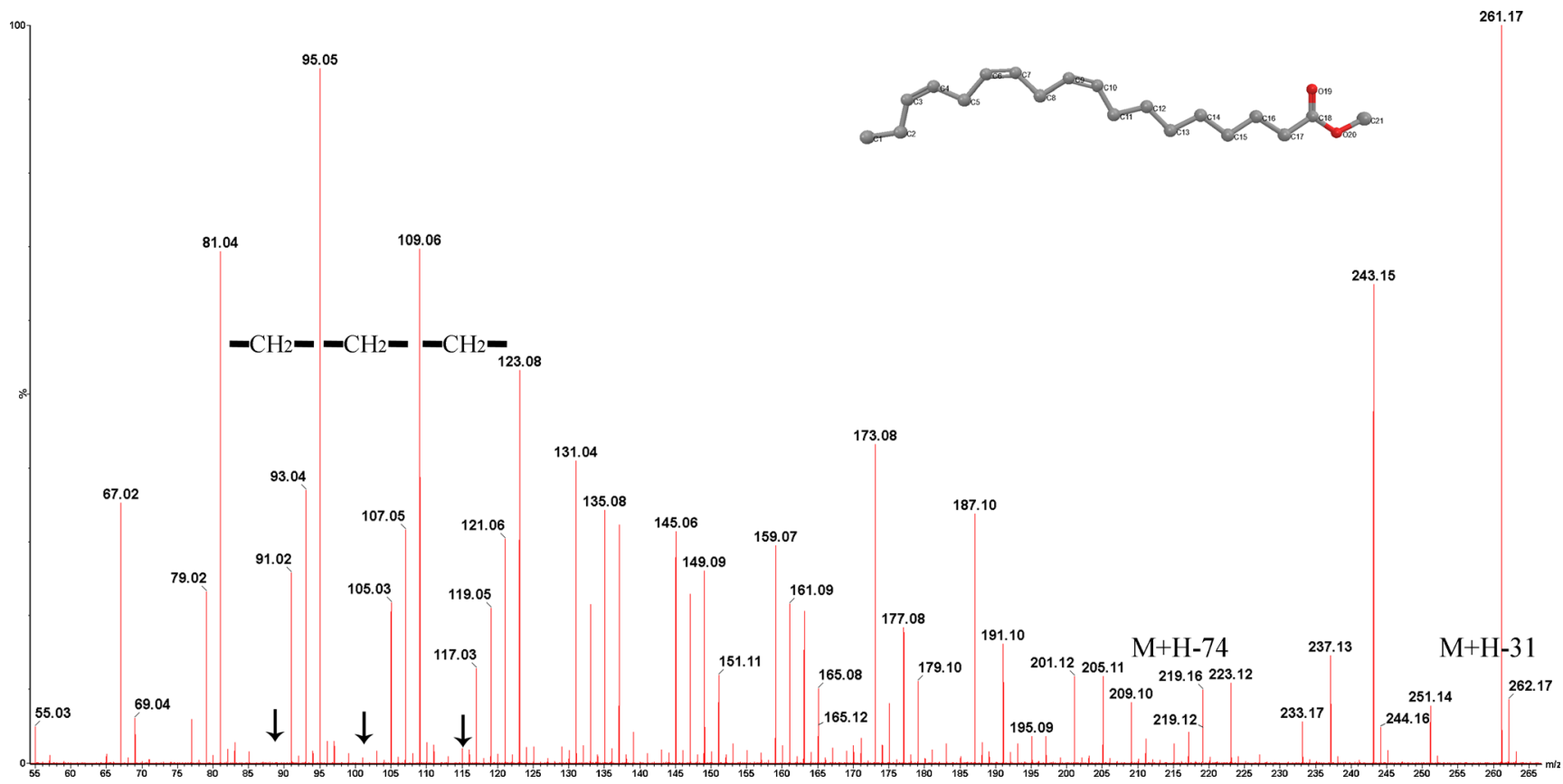

Fig. 6 Linolenic methyl ester fragmentation patterns. The molecular structure of this FAME and the $\mathrm{CH}_{2}$ loss are shown in detail. The arrows indicate the ion series of $87 \mathrm{~m} / \mathrm{z}$ 


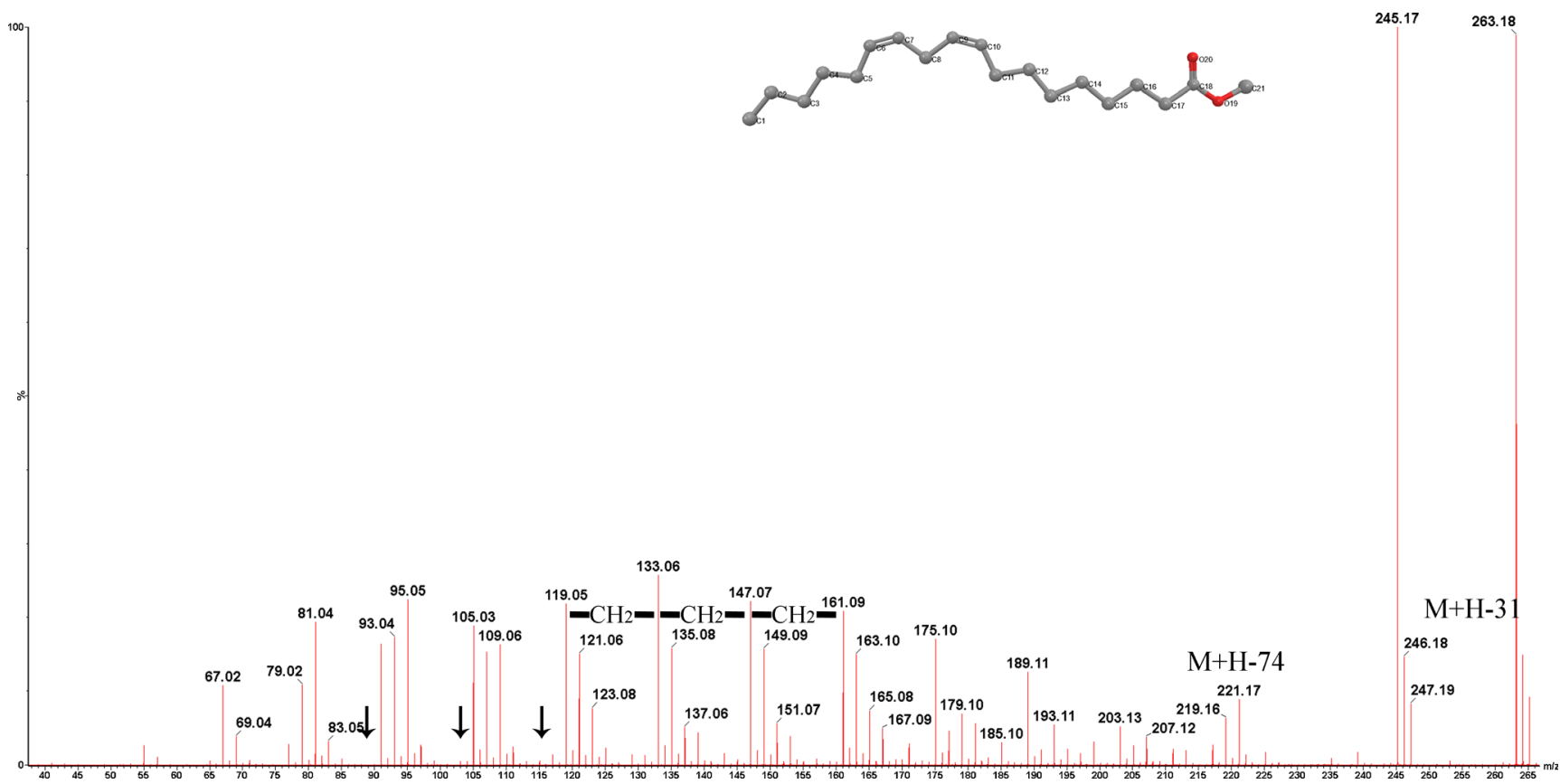

Fig. 7 Linoleic methyl ester fragmentation patterns. The molecular structure of this FAME and the $\mathrm{CH}_{2}$ loss are shown in detail. The arrows indicate the ion series of $87 \mathrm{~m} / \mathrm{z}$

Table 2 Mass values $(\mathrm{m} / \mathrm{z})$ of important ions and series as determined by the mass spectrometry experiments. The ion series $(\mathrm{M}+\mathrm{H}-18)$ corresponds to a possible water loss. Ion series $(\mathrm{M}+\mathrm{H}-50)$ corresponds to a possible rearrangement in carbonic chain with a water loss $\left(\mathrm{C}_{2} \mathrm{H}_{3}+3 \mathrm{H}+\right.$ $\mathrm{H}_{2} \mathrm{O}$ ). Ion series 87 was described by Mclafferty $[28,18]$. Ion series 55 and 53 was observed in the spectra

\begin{tabular}{|c|c|c|c|c|c|c|c|c|c|c|c|c|c|c|c|c|c|c|c|}
\hline & $m / z$ & $\mathrm{C} 18$ & $\mathrm{C} 17$ & $\mathrm{C} 16$ & $\mathrm{C} 15$ & $\mathrm{C} 14$ & $\mathrm{C} 13$ & $\mathrm{C} 12$ & $\mathrm{C} 11$ & $\mathrm{C} 10$ & C9 & $\mathrm{C} 8$ & $\mathrm{C} 7$ & $\mathrm{C} 6$ & $\mathrm{C} 5$ & $\mathrm{C} 4$ & $\mathrm{C} 3$ & $\mathrm{C} 2$ & $\mathrm{C} 1$ \\
\hline \multirow[t]{5}{*}{ Palmitic } & $\mathrm{M}+\mathrm{H}$ & & & 271 & 257 & 243 & 229 & 215 & 201 & 187 & 173 & 159 & 145 & 131 & 117 & 103 & 89 & 75 & 61 \\
\hline & $\mathrm{M}+\mathrm{H}-18$ & & & 253 & 239 & 225 & 211 & 197 & 183 & 169 & 155 & 141 & 127 & 113 & 99 & 85 & 71 & 57 & 43 \\
\hline & $\mathrm{M}+\mathrm{H}-50$ & & & & & & 221 & 207 & 193 & 179 & 165 & 151 & 137 & 123 & 109 & 95 & 81 & 67 & 53 \\
\hline & Ion series 87 & & & 87 & 101 & 115 & 129 & 143 & 157 & 171 & 185 & 199 & 213 & 227 & 241 & 255 & & & \\
\hline & Ion series 55 & & & 55 & 69 & 83 & 97 & 111 & 125 & 139 & 153 & 167 & 181 & 195 & 209 & 223 & 237 & & \\
\hline \multirow[t]{6}{*}{ Linolenic } & $\mathrm{M}+\mathrm{H}$ & 293 & 279 & 265 & 251 & 237 & 223 & 209 & 195 & 181 & 167 & 153 & 139 & 125 & 111 & 97 & 83 & 69 & 55 \\
\hline & $\mathrm{M}+\mathrm{H}-18$ & 275 & 261 & 247 & 233 & 219 & 205 & 191 & 177 & 163 & 149 & 135 & 121 & 107 & 93 & 79 & 65 & & \\
\hline & $\mathrm{M}+\mathrm{H}-50$ & & & & 243 & 229 & 215 & 201 & 187 & 173 & 159 & 145 & 131 & 117 & & & & & \\
\hline & Ion series 87 & 87 & 101 & 115 & 129 & 143 & 157 & 171 & 185 & 199 & 213 & 227 & & & & & & & \\
\hline & Ion series 55 & 55 & 69 & 83 & 97 & 111 & 125 & 139 & 153 & 167 & 181 & 195 & 209 & 223 & 237 & 251 & & & \\
\hline & Ion series 53 & 53 & 67 & 81 & 95 & 109 & 123 & 137 & 151 & 165 & 179 & & & & & & & & \\
\hline \multirow[t]{6}{*}{ Linoleic } & $\mathrm{M}+\mathrm{H}$ & 295 & 281 & 267 & 253 & 239 & 225 & 211 & 197 & 183 & 169 & 155 & 141 & 127 & 113 & 99 & 85 & 71 & 57 \\
\hline & $\mathrm{M}+\mathrm{H}-18$ & 277 & 263 & 249 & 235 & 221 & 207 & 193 & 179 & 165 & 151 & 137 & 123 & 109 & 95 & 81 & 67 & & \\
\hline & $\mathrm{M}+\mathrm{H}-50$ & & & & 245 & 231 & 217 & 203 & 189 & 175 & 161 & 147 & 133 & 119 & 105 & 91 & 77 & & \\
\hline & Ion series 87 & 87 & 101 & 115 & 129 & 143 & 157 & 171 & 185 & 199 & 213 & 227 & & & & & & & \\
\hline & Ion series 55 & 55 & 69 & 83 & 97 & 111 & 125 & 139 & 153 & 167 & 181 & 195 & 209 & & & & & & \\
\hline & Ion series 53 & 53 & 67 & 81 & 95 & 109 & 123 & 137 & 151 & 165 & 179 & & & & & & & & \\
\hline \multirow[t]{6}{*}{ Oleic } & $\mathrm{M}+\mathrm{H}$ & 297 & 283 & 269 & 255 & 241 & 227 & 213 & 199 & 185 & 171 & 157 & 143 & 129 & 115 & 101 & 87 & 73 & 59 \\
\hline & $\mathrm{M}+\mathrm{H}-18$ & 279 & 265 & 251 & 237 & 223 & 209 & 195 & 181 & 167 & 153 & 139 & 125 & 111 & 97 & 83 & 69 & & \\
\hline & $\mathrm{M}+\mathrm{H}-50$ & & & & 247 & 233 & 219 & 205 & 191 & 177 & 163 & 149 & 135 & 121 & 107 & 93 & 79 & & \\
\hline & Ion series 87 & 87 & 101 & 115 & 129 & 143 & 157 & 171 & 185 & 199 & 213 & 227 & & & & & & & \\
\hline & Ion series 55 & 55 & 69 & 83 & 97 & 111 & 125 & 139 & 153 & 167 & 181 & 195 & 209 & & & & & & \\
\hline & Ion series 53 & 53 & 67 & 81 & 95 & 109 & 123 & 137 & 151 & 165 & 179 & & & & & & & & \\
\hline
\end{tabular}




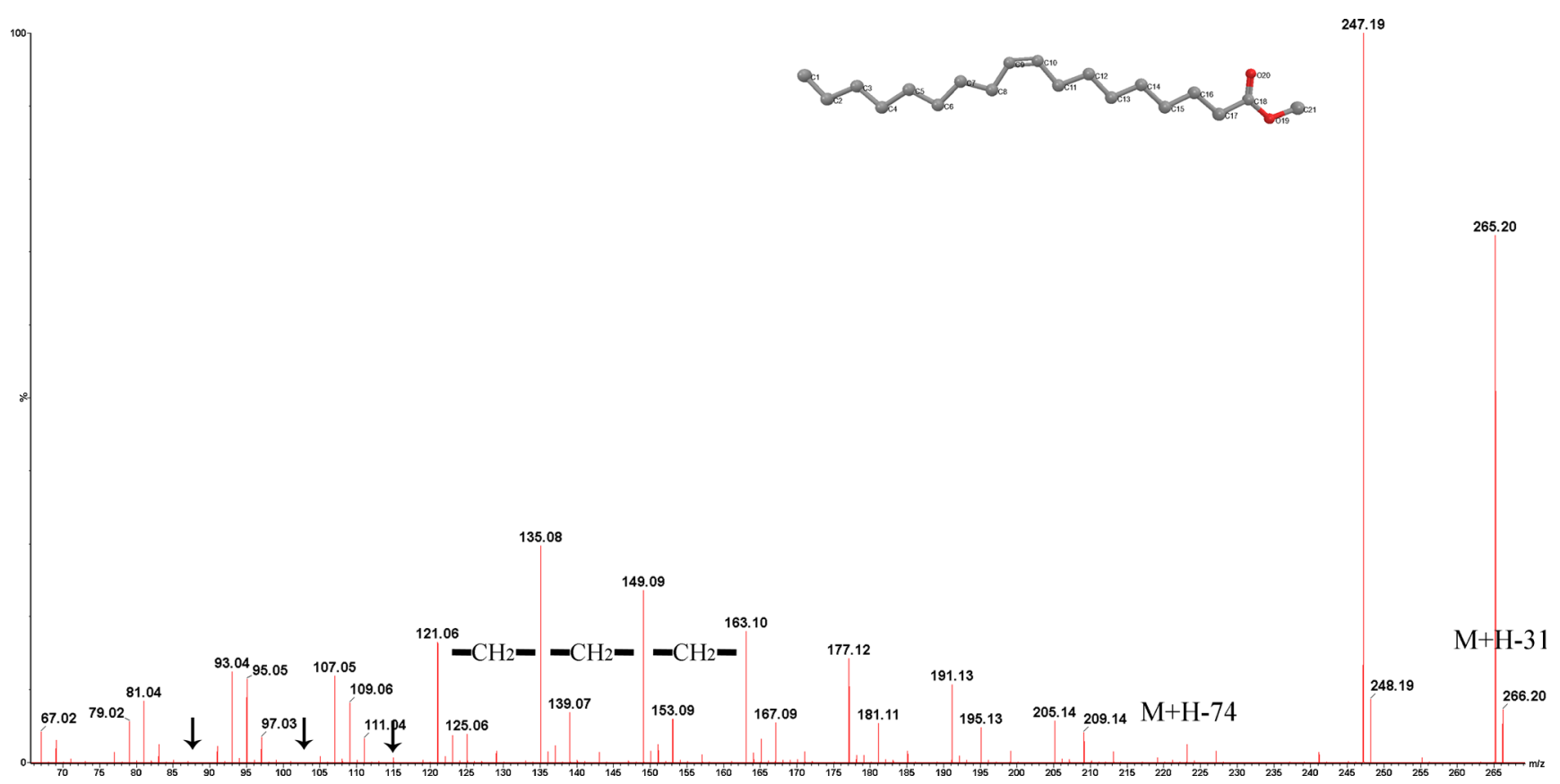

Fig. 8 Oleic methyl ester fragmentation patterns. The molecular structure of this FAME and the $\mathrm{CH}_{2}$ loss are shown in detail. The arrows indicate the ion series of $87 \mathrm{~m} / \mathrm{z}$

\section{Results and discussion}

\section{Soybean transformation}

Transgenic soybean plants were generated by co-bombardment using a developed protocol as previously described [24]. The microparticle bombardment experiments included 3,600 embryonic axes. The embryonic axes were cultured in vitro for 6 weeks, and the putative transgenic plantlets were analysed via PCR. Eight independent soybean $\mathrm{T}_{0}$ lines were obtained and presented both the 728 and $835 \mathrm{bp}$ fragments corresponding to two internal regions of the pSoybiofuell vector expression cassette that were amplified using the KANNIf/PDKr and PDKf/KANNIr primer combinations, respectively. The transgenic plants were also analysed for the presence of the selectable marker gene, ahas [25]. All transgenic plantlets presented the $685 \mathrm{bp}$ fragment corresponding to the amplification of the $5^{\prime}$ internal segment of the mutated ahas gene. The transgenic plants were transferred to soil under greenhouse conditions to set seeds. The $T_{1}$ heterozygous individual seed lines were then analysed by mass spectrometry to evaluate the oil composition and structure.

\section{GC-MS analysis}

After soybean oil extraction and derivatisation, the methyl esters were analysed by GC-MS (Table 1; Figs. 1 and 2). Different $T_{1}$ lines exhibited an improved profile for production of oleic acid and a reduction in palmitic acid (Electronic Supplementary Material, Table S1). Seed line 65-25 presented the highest performance with $94.58 \%$ oleic acid and $2.12 \%$ palmitic acid (Table 1). To verify the extraction and derivatisation stability over time, lines 65-25, 65-14 and 122-22 were injected into the GC-MS once a week throughout the analytical experiments. The standard deviations (Table 1) demonstrated that the analyses can be performed with a week between the extraction, derivatisation and GC-MS analysis without significant variation in the results. Furthermore, the 65-25 line presented higher concentrations of oleic acid and lower concentrations of palmitic acid than the oil extracted from the non-transgenic seeds (Fig. 1) [10], suggesting that the structural oil characteristics determined in line 65-25 meet the international standards for biodiesel production [10]. Thus, all $\mathrm{T}_{2}$ seeds (Table 1) were generated from line 65-25.

Ion mobility analysis

The structural characterisation of the fatty acid profile in the transgenic and non-transgenic soybean seeds was performed using high-resolution/accurate mass spectrometry and ion mobility-MS. The exact mass spectra of line 65-25 (Fig. 3) indicated no change in the masses of palmitic methyl ester $(271.2[\mathrm{M}+\mathrm{H}] \mathrm{m} / \mathrm{z})$, linolenic methyl ester $(293.2[\mathrm{M}+\mathrm{H}] \mathrm{m} /$ $z)$, linoleic methyl ester $(295.2[\mathrm{M}+\mathrm{H}] \mathrm{m} / \mathrm{z})$ and oleic methyl ester $(297.2[\mathrm{M}+\mathrm{H}] \mathrm{m} / \mathrm{z})$. However, the mass of stearic methyl ester $(299.2[\mathrm{M}+\mathrm{H}] \mathrm{m} / \mathrm{z})$ could not be determined because it matched that of one isotope of oleic methyl ester, resulting in a contaminated fragmentation spectrum.

Figures 5, 6, 7 and 8 demonstrate the fragmentation of the fatty acid methyl esters (FAMEs). The results indicate no 
differences between the standard spectra and those of the soybean 65-25 esterified oil. The fragmentation process in the collision cell produces ions that can be assigned as signatures for the FAMEs. Figure 4 shows the three most common FAME rearrangements due to the fragmentation process. The Mclafferty rearrangement often occurs [28, 18], forming ions with $\mathrm{M}+\mathrm{H}-31$ and $\mathrm{M}+\mathrm{H}-74$ (Fig. 4b, c). The hydrocarbon chain has a signature of $\mathrm{M}+\mathrm{H}-14$, corresponding to the consecutive break of $\mathrm{CH}_{2}$. A series of ions was also detected based on the $87 \mathrm{~m} / \mathrm{z}$ ion (Fig. 4a), forming ions with masses of $101,115,129$ and $143 \mathrm{~m} / z\left(\mathrm{CH}_{3} \mathrm{OCO}\left[\mathrm{CH}_{2}\right]_{N}\right)$ with low intensity. These signatures can be observed in Figs. 5, 6, 7 and 8,
Fig. 9 Ion mobility analysis of the FAMEs from transgenic and non-transgenic seeds. A

Superimposition of the drift time for each analysed FAME. B 3D representation of the positions of the FAMEs in the drift tube and their isotopes a

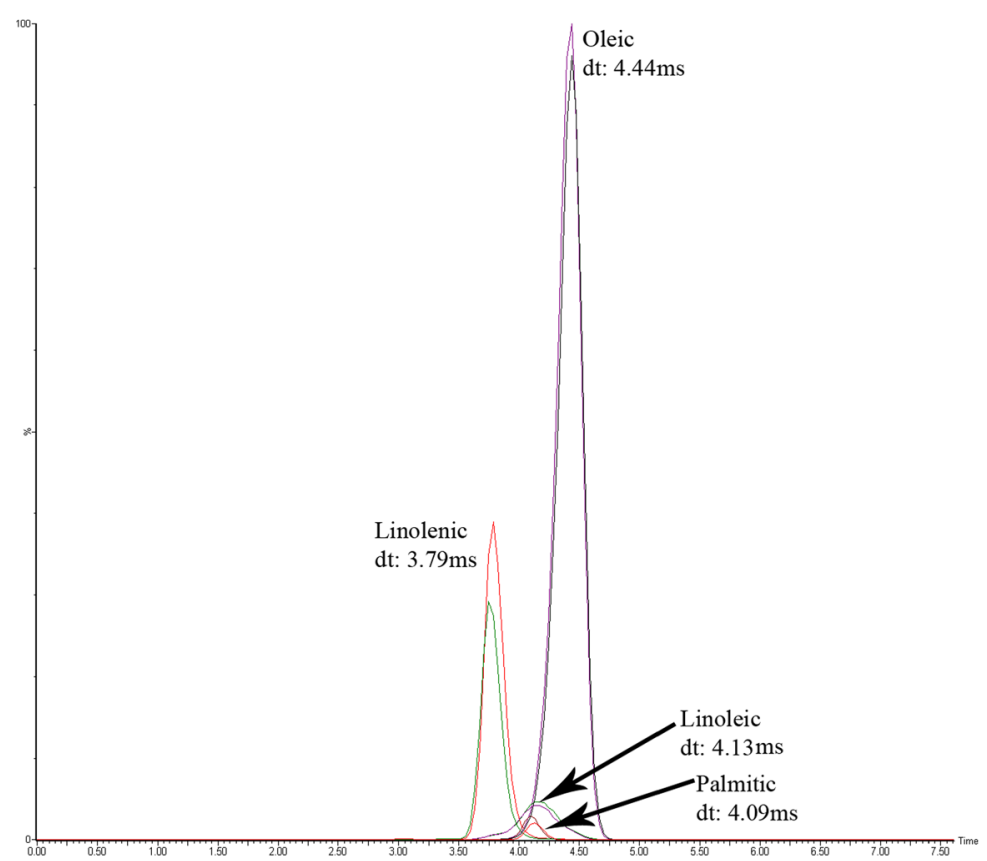

b
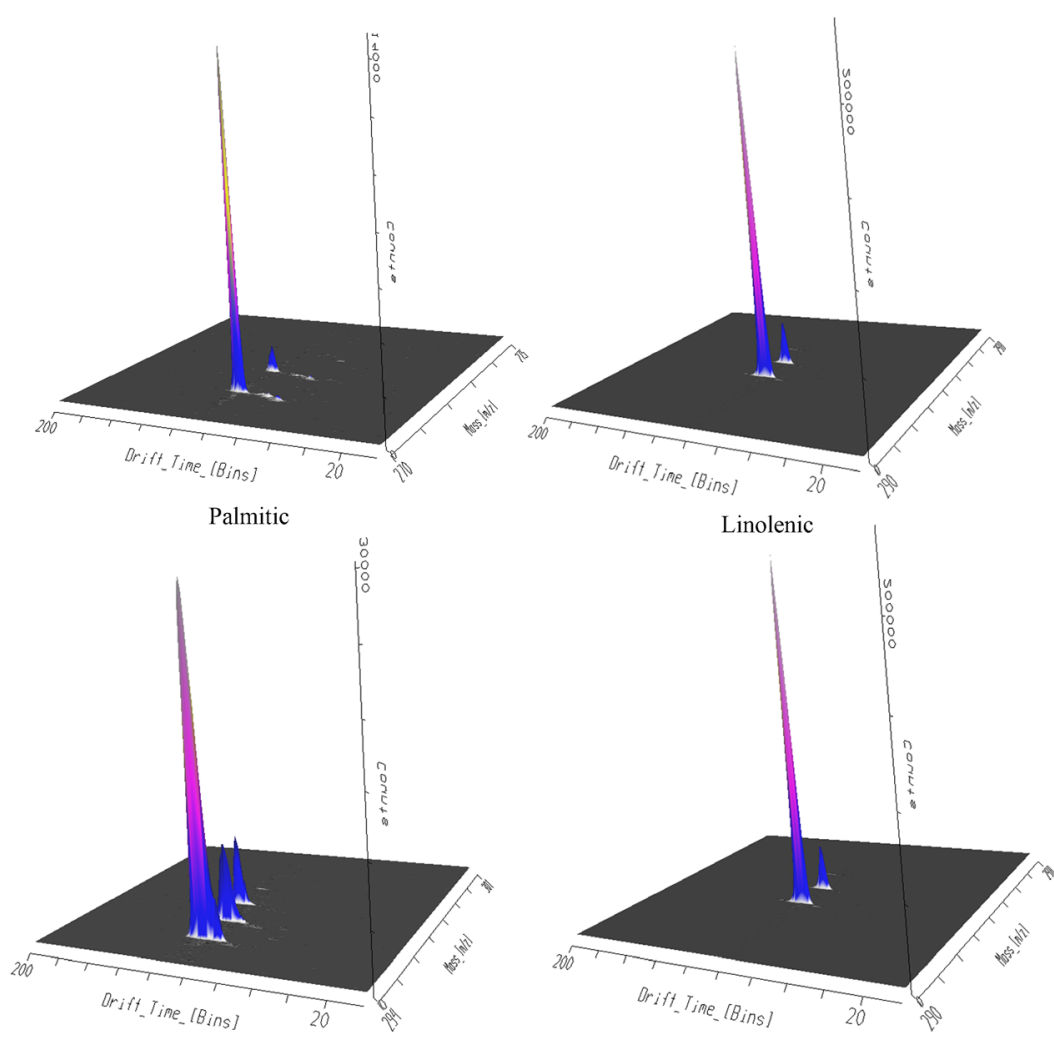

Oleic 
which depict ions $197 \mathrm{~m} / \mathrm{z}$ and $240 \mathrm{~m} / z$ for palmitic acid, 225 $\mathrm{m} / \mathrm{z}$ and $268 \mathrm{~m} / \mathrm{z}$ for stearic acid, $223 \mathrm{~m} / \mathrm{z}$ and $266 \mathrm{~m} / \mathrm{z}$ for oleic acid, $262 \mathrm{~m} / \mathrm{z}$ and $219 \mathrm{~m} / \mathrm{z}$ for linolenic acid and $264 \mathrm{~m} / \mathrm{z}$ and $221 \mathrm{~m} / \mathrm{z}$ for linoleic acid, representing $\mathrm{M}+\mathrm{H}-31$ and $\mathrm{M}+\mathrm{H}-74$, respectively. In addition, Table 2 contains a list of all relevant masses found in the spectra. We found a series of ions that have $\mathrm{M}+\mathrm{H}-18, \mathrm{M}+\mathrm{H}-50$ as precursors with two other series that start with ions of $55 \mathrm{~m} / \mathrm{z}$ and $53 \mathrm{~m} / \mathrm{z}$. These ions were also detected in the GC-MS spectra (data not shown). We can theorise that $\mathrm{M}+\mathrm{H}-18$ represents the resulting water loss in the compound, $\mathrm{CH}_{3}\left(\mathrm{CH}_{2}\right)_{N} \mathrm{CCHOCH}_{2}+\mathrm{H}_{2} \mathrm{O}$. The M+H-50 series could be a multiple rearrangement of the hydrocarbon chain following water loss $\left(\mathrm{CHCCC}\left[\mathrm{CH}_{2}\right]_{\mathrm{N}} \mathrm{COCH}_{2}+\mathrm{C}_{2} \mathrm{H}_{5}+\right.$ $3 \mathrm{H}+\mathrm{H}_{2} \mathrm{O}$ ). The ion series starting at $55 \mathrm{~m} / \mathrm{z}$ could begin with a compound modified from Fig. $4 \mathrm{~b}, \mathrm{CH}_{2} \mathrm{CH}\left(\mathrm{CH}_{2}\right)_{N} \mathrm{CO}$. We do not believe that these ions could be formed by contamination either in the ion source or in the sample because the ion mobility of each methyl ester exhibited only one conformation (Fig. 9), indicating that the observed fragments were obtained from ions isolated from the quadrupole.

Furthermore, the ion mobility of each FAME was evaluated for multiple structures and/or contamination between line 6525 and a non-transgenic line. The results are provided in Fig. 9, with the following drift times for each FAME: palmitic $=4.09 \mathrm{~ms}$, linolenic $=3.79 \mathrm{~ms}$, linoleic $=4.13 \mathrm{~ms}$ and oleic $=4.44 \mathrm{~ms}$ (Fig. 9a). Figure 9b depicts the isotopes of each FAME, showing a uniform distribution. These data indicate that a single structural conformation is formed, and no difference is observed between the FAMEs from line 65-25 and those from the non-transgenic line.

These results are in agreement with the analysis and comparison of the soybean oil samples from the transgenic and non-transgenic lines previously performed by other groups using different techniques [23, 9]. For example, Luna et al. [29] analysed the oil content from transgenic and nontransgenic soybean seeds using infrared spectroscopy to distinguish and classify the soybean oil for process monitoring and control. Their results indicated no significant differences among the samples. Similar results were observed by Graef et al. [10], who compared oil performance from transgenic soybean seeds and demonstrated improved quality in transgenic lines for the production of oil for biofuel.

Historically, vegetable oils have been of great industrial importance in the preparation of margarines and other foodstuffs. They have now become important as raw materials for biofuel. The worldwide demand for vegetable oil for both foods and biofuels requires increased production. Biotechnology presents a variety of solutions to improve the fatty acid composition for food and industrial uses. Through metabolic engineering, the oil content can be altered in a variety of crops, such as soybeans, to produce the oils needed by industry. For example, the omega-3 polyunsaturated fatty acids found in fish oil can now be produced in plants [30], improving the quality of food for humans and animals. Each gene responsible for the production of oil in soybeans has been identified [10, 27, 31-33] and we have developed a soybean line that expresses an oleic acid content of up to $95 \%$ and a palmitic acid content below $4 \%$. The oils from the metabolically engineered soybean seed lines produced have similar structural characteristics to those from nontransgenic seeds. These lines may form the foundation for the next generation of homozygous lines and the large-scale production of improved performance oils for the bioenergy sector.

\section{Conclusions}

Metabolically engineered soybean plants exhibited a significant increase in oleic acid and a reduction in palmitic acid in their seed oil content. Structural characterisation, performed using highresolution/accurate mass spectrometry and ion mobility-MS, revealed no differences in the fatty acids of the transgenic and non-transgenic oil extracts. Using this approach, it is possible to check potential modifications in the first plant generation, keeping the seeds viable for germination and progeny development

Acknowledgments The authors would like to thank Dr. Carlos Bloch for his contribution to the structural determination and Luis Carlos Lemos, Josué Ignácio Lemos, Pedro de Souza, Jorge Alex Taquita and Luciana F. de Oliveira for their technical assistance. This research was supported in part by the National Council for Scientific and Technological Development (CNPq), Fundação de Apoio a Pesquisa do DF (FAPDF) and the Brazilian Agricultural Research Corporation (Embrapa).

\section{References}

1. Durrett TP, Benning C, Ohlrogge J (2008) Plant triacylglycerols as feedstocks for the production of biofuels. Plant J 54(4):593-607

2. Batten D, Beer T, Freischmidt G, Grant T, Liffman K, Paterson D, Priestley T, Rye L, Threlfall G (2013) Using wastewater and highrate algal ponds for nutrient removal and the production of bioenergy and biofuels. Water Sci Technol 67(4):915-924

3. Zhang F, Ouellet M, Batth TS, Adams PD, Petzold CJ, Mukhopadhyay A, Keasling JD (2012) Enhancing fatty acid production by the expression of the regulatory transcription factor FadR. Metab Eng 14(6):653-660

4. Shi S, Valle-Rodriguez JO, Khoomrung S, Siewers V, Nielsen J (2012) Functional expression and characterization of five wax ester synthases in Saccharomyces cerevisiae and their utility for biodiesel production. Biotechnol Biofuels 5:7

5. Fehr WR (2007) Breeding for modified fatty acid composition in soybean. Crop Sci 47:S72-S87

6. Koria L, Nithya G (2012) Analysis of Datura stramonium Linn. biodiesel by gas chromatography - mass spectrometry (gc-ms) and influence of fatty acid composition on the fuel related characteristics. J Phytol 4(1):06-09

7. Frankel EN (1980) Lipid oxidation. Prog Lipid Res 19(1-2):1-22

8. Canakci M, Monyem A, Van Gerpen J (1999) Accelerated oxidation processes in biodiesel. Trans ASAE 42(6): 1565-1572

9. Duffield JA (2007) Biodiesel: production and economic issues. Inhal Toxicol 19(12):1029-1031 
10. Graef G, LaVallee BJ, Tenopir P, Tat M, Schweiger B, Kinney AJ, Van Gerpen JH, Clemente TE (2009) A high-oleic-acid and lowpalmitic-acid soybean: agronomic performance and evaluation as a feedstock for biodiesel. Plant Biotechnol J 7(5):411-421

11. Patil A, Taware SP, Oak MD, Tamhankar SA, Rao VS (2007) Improvement of oil quality in soybean [Glycine max (L.) Merrill] by mutation breeding. J Am Oil Chem Soc 84(12):1117-1124

12. Clemente TE, Cahoon EB (2009) Soybean oil: genetic approaches for modification of functionality and total content. Plant Physiol 151(3):1030-1040

13. Qian J, Shi H, Yun Z (2010) Preparation of biodiesel from Jatropha curcas L. oil produced by two-phase solvent extraction. Bioresour Technol 101(18):7036-7042

14. Berchmans HJ, Hirata S (2008) Biodiesel production from crude Jatropha curcas L. seed oil with a high content of free fatty acids. Bioresour Technol 99(6):1716-1721

15. Worapun I, Pianthong K, Thaiyasuit P (2012) Two-step biodiesel production from crude Jatropha curcas L. oil using ultrasonic irradiation assisted. J Oleo Sci 61(4):165-172

16. Qu J, Mao HZ, Chen W, Gao SQ, Bai YN, Sun YW, Geng YF, Ye J (2012) Development of marker-free transgenic Jatropha plants with increased levels of seed oleic acid. Biotechnol Biofuels 5(1):10

17. Chai C, Ju HK, Kim SC, Park JH, Lim J, Kwon SW, Lee J (2012) Determination of bioactive compounds in fermented soybean products using GC/MS and further investigation of correlation of their bioactivities. J Chromatogr B Analyt Technol Biomed Life Sci 880(1):42-49

18. Mclafferty FW, Gohlke RS (1959) Mass spectrometric analysisaromatic acids and esters. Anal Chem 31(12):2076-2082

19. Christie WW (1998) Gas chromatography-mass spectrometry methods for structural analysis of fatty acids. Lipids 33(4):343-353

20. Cahoon EB, Shanklin J (2000) Substrate-dependent mutant complementation to select fatty acid desaturase variants for metabolic engineering of plant seed oils. P Natl Acad Sci U S A 97(22):1235012355

21. Dormann P, Frentzen M, Ohlrogge JB (1994) Specificities of the acyl-acyl carrier protein (Acp) Thioesterase and glycerol-3phosphate acyltransferase for octadecenoyl-Acp isomers - identification of a petroselinoyl-Acp thioesterase in Umbelliferae. Plant Physiol 104(3):839-844
22. Broun P, Boddupalli S, Somerville C (1998) A bifunctional oleate 12hydroxylase: desaturase from Lesquerella fendleri. Plant J 13(2): 201-210

23. Wesley SV, Helliwell CA, Smith NA, Wang MB, Rouse DT, Liu Q, Gooding PS, Singh SP, Abbott D, Stoutjesdijk PA, Robinson SP, Gleave AP, Green AG, Waterhouse PM (2001) Construct design for efficient, effective and high-throughput gene silencing in plants. Plant J 27(6):581-590

24. Rech EL, Vianna GR, Aragao FJL (2008) High-efficiency transformation by biolistics of soybean, common bean and cotton transgenic plants. Nat Protoc 3(3):410-418

25. Aragão FJL, Sarokin L, Vianna GR, Rech EL (2000) Selection of transgenic meristematic cells utilizing a herbicidal molecule results in the recovery of fertile transgenic soybean [Glycine max (L.) Merril] plants at a high frequency. Theor Appl Genet 101(1-2):1-6

26. Doyle JJ, Doye JL (1987) Rapid DNA isolation procedure from small quantities of fresh leaf tissues. Phytochem Bull 19(1):11-15

27. Primomo VS, Falk DE, Ablett GR, Tanner JW, Rajcan I (2002) Inheritance and interaction of low palmitic and low linolenic soybean. Crop Sci 42(1):31-36

28. Mclafferty FW (1959) Mass spectrometric analysis - molecular rearrangements. Anal Chem 31(1):82-87

29. Luna AS, da Silva AP, Pinho JSA, Ferre J, Boque R (2013) Rapid characterization of transgenic and non-transgenic soybean oils by chemometric methods using NIR spectroscopy. Spectrochim Acta A 100:115-119

30. Truksa M, Wu GH, Vrinten P, Qiu X (2006) Metabolic engineering of plants to produce very long-chain polyunsaturated fatty acids. Transgenic Res 15(2):131-137

31. Li R, Hatanaka T, Yu K, Wu Y, Fukushige H, Hildebrand D (2013) Soybean oil biosynthesis: role of diacylglycerol acyltransferases. Funct Integr Genomics 13:99-113

32. Heppard EP, Kinney AJ, Stecca KL, Miao GH (1996) Developmental and growth temperature regulation of two different microsomal omega-6 desaturase genes in soybeans. Plant Physiol 110(1):311319

33. Tang GQ, Novitzky WP, Griffin HC, Huber SC, Dewey RE (2005) Oleate desaturase enzymes of soybean: evidence of regulation through differential stability and phosphorylation. Plant J 44(3): $433-446$ 